\title{
The Modification of System for the Angle of Attack Setting at Roller Rig RAILBCOT
}

\section{Veronika Štefaňaková, Lenka Valčáková}

University of Žilina, Faculty of Mechanical Engineering, Department of Transport and Handling Machines, Univerzitná 1, 01026 Žilina, e-mail: veronika.stefanakova@fstroj.uniza.sk, lenka.valcakova@fstroj.uniza.sk

The aim of the article is to present suitable changes at the conception of the angle of attack setting mechanism and the modification of the spring element at the load module SIMRAIL, part of roller rig RAILBCOT which faithfully simulates the behavior of the vehicle on a real track. RAILBCOT is the acronym for RAIL vehicles Brake COmponents Test stand. During the measurements were recorded imperfections, which could influence continuous testing, and would lead not to reliable and fully trusworthy results. The article describes three steps to improve the situation. The first step describes the stabilization of the members to prevent the occurrence of clearance. In the second step were started measurements at the roller rig at different operating speeds. In the third step is modified the angle of attack setting mechanism where was mechanical spring element changed by hydraulic spring element. Mentioned is also the need for increasing the stiffness of the spring element, which lack of stiffness caused loss of stability before the requesting speed. Modified was the gear lever, where was changed the transmission ratio and dimensioning of spring element.

Key words: RAILBCOT, SIMRAIL, test stand, rail vehicle brakes, simulation computations

\section{Acknowledgement}

The work was supported by the Scientific Grant Agency of the Ministry of Education of the Slovak Republic and the Slovak Academy of Sciences in project No. 1/0347/12: “Railway wheel tread profile wear research under the rail vehicle in operation conditions simulation on the test bench", project No. 1/0383/12: "The rail vehicle running properties research with the help of a computer simulation." and the project No. APVV-0842-11: "Equivalent railway operation load simulator on the roller rig”.

\section{Research-Educational Center of Rail Vehicles (VVCKV)}

\section{References}

[1] GERLICI, J., VESELÝ, P., LACK, T. (2001). Thermic loading of railway wheel on when braking. In: Communications - scientific letters of the University of Žilina. ISSN 1335-4205. - č. 1 (2001), (pp. 77-87).

[2] GERLICI, J., LACK, T. (2003). Rail geometry analysis (from the point of view of wearing in the operation). In: Communications - scientific letters of the University of Žilina. ISSN 1335-4205. - Vol. 5, No. 1 (2003), (pp. 4351).

[3] GERLICI, J., LACK, T., LACKOVÁ, M. (2004). Calculation of the equivalent conicity function of the railway wheelset tread profile at the Delta $\mathrm{R}$ function with a negative slope. In: Communications - scientific letters of the University of Žilina. ISSN 1335-4205. - Vol. 6, Nr. 2 (2004), (pp. 49-56).

[4] GERLICI, J., LACK, T. (2005). Wheelset/rail geometric characteristics assessment with regard to wheelset rolling. In: Communications - scientific letters of the University of Žilina. ISSN 1335-4205. - Roč. 7, č. 1 (2005), (pp. 5$10)$.

[5] GERLICI, J., LACK, T. (2010). Contact geometry influence on the rail / wheel surface stress distribution. In: Procedia Engineering. ISSN 1877-7058. - Iss. 1 (2010), (pp. 2249-2257).

[6] Gerlici, J., Lack, T. (2011): Railway wheel and rail head profiles development based on the geometric characteristics shapes. In: Wear : an international journal on the science and technology of friction, lubrication and wear. ISSN 0043-1648. - Vol. 271, No. 1-2 Sp. iss. (2011), (pp. 246-258).

[7] LACK, T., GERLICI, J. (2005). Contact area and normal stress determination on railway wheel / rail contact. In: Communications - scientific letters of the University of Žilina. ISSN 1335-4205. - Roč. 7, č. 2 (2005), (pp. 38-45).

[8] LACK, T., GERLICI, J. (2012). Wheel / rail contact stress evaluation by means of the modified strip method utilization. In: VSDIA 2012: proceedings of the 13th mini conference on Vehicle system dynamics, identification and anomalies: 5-7 November, 2012 Budapest, Hungary. - [S.1.: s.n.], 2012. - ISBN 978-963-313-102-2, (pp. 261269). 
[9] LACK, T., GERLICI, J. (2013). Wheel/rail contact stress evaluation by means of the modified Strip method. In: Communications: scientific letters of the University of Žilina. ISSN 1335-4205. - Vol. 15, no. 3 (2013), (pp. 126132).

[10] LACK, T., GERLICI, J. (2013). The FASTSIM method modification in speed up the calculation of tangential contact stresses between wheel and rail. In: Manufacturing technology: journal for science, research and production. ISSN 1213-2489. - Vol. 13, no. 4 (2013), (pp. 486-492).

[11] LACK, T., GERLICI, J. (2014). A modified strip method to speed up the tangential stress between wheel and rail calculation. In: Applied mechanics and materials. - ISSN 1660-9336. - Vol. 486 (2014), online ISSN 1662-7482, (pp. 371-378).

[12] LACK, T., GERLICI, J. (2014). Wheel/rail tangential contact stress evaluation by means of the modified strip method. In: Communications : scientific letters of the University of Žilina. ISSN 1335-4205. - Vol. 16, no. 3A (2014), (pp. 33-39).

[13] SVOBODA, M., SOUKUP, J. (2013). Verification of numeric solution by experiment for examination vertical oscillation of a mechanical system. In: Manufacturing Technology. ISSN 1213-2489, 2013, vol. 13, iss. 4, (pp. 559-563).

[14] GERLICI, J., LACK, T., HARUŠINEC, J., MÜLLER, R., DOLEŽEL, P. (2011). Rail vehicles brake components test stand. (In Slovak). In: PRORAIL 2011: Žilina, 21.-23.9.2011, conference proceedings. - Žilina: Scientific and Technical Society at the University of Žilina, 2011. ISBN 978-80-89276-30-1, (pp. 233-241).

[15] GERLICI, T., LACK, T., HARUŠINEC, J. (2012). Test stand properties analysis for wheel-tread wear in accordance with the laboratory simulated railway operation. In: VSDIA 2012 : proceedings of the 13th mini conference on Vehicle system dynamics, identification and anomalies: 5-7 November, 2012 Budapest, Hungary. - [S.1.: s.n.], 2012. - ISBN 978-963-313-102-2, (pp. 157-165).

[16] GERLICI, J., LACK, T., HARUŠINEC, J. (2012). RAILBCOT - Rail vehicles brake components test stand (In Slovak). Computational and experimental methods in applied mechanics. - Ústí nad Labem: Faculty of production technologies and management University J. E. Purkyně, 2012). ISBN 978-80-7414-377-9, (pp. 165-172).

[17] GERLICI, J., LACK, T., HARUŠINEC, J. (2012). RAILBCOT - the rail vehicles brake components test stand (In Slovak). In: Computational and experimental methods in applied mechanics. - Ústí nad Labem: UJEP, 2012. ISBN 978-80-7414-377-9, (pp. 165-172).

[18] VALČÁKOVÁ, L., LACK, T., GERLICI, J., HARUŠINEC, J. (2013). Rail vehicles brake components test stand dynamic properties evaluation. In: TRANSCOM 2013: 10-th European conference of young researchers and scientists: Žilina, June 24-26, 2013, Slovak Republic. - Žilina: University of Žilina, 2013. - ISBN 978-80-554-0695-4, (pp. 321-324).

[19] GERLICI, J., LACK, T., HARUŠINEC, J. (2013). Wheels tread wear stand analysis in accordance to the laboratory simulated railway operation. In: Dynamical problems in rail vehicles 2013: Slovak - Polish scientific workshop: Žilina June 24th and 25th, 2013 Slovak Republic. Žilina: University of Žilina, Department of Transport and Handling Machines. ISBN 978-80-554-0841-5, (pp. 40-55).

[20] GERLICI, J., LACK, T., HARUŠINEC, J. (2014). Development of test stand prototype for rail vehicles brake components testing. In: Communications - scientific letters of the University of Žilina. ISSN 1335-4205. - Vol. 16, no. 3A (2014), (pp. 27-32).

[21] GERLICI, J., LACK, T., HARUŠINEC, J. (2014). Realistic simulation of railway operation on the RAILBCOT test stand. In: Applied mechanics and materials. ISSN 1660-9336. - Vol. 486 (2014), online ISSN 1662-7482, (pp. 387-395).

[22] GERLICI, J., LACK, T., DOLEŽEL, P., HARUŠINEC, J. (2014). Test stand mechanical system dynamics analysis. In: Prace Naukowe. Transport: Analiza i ocena elementów systemów transportowych. ISSN 1230-9265. - Z. 101 (2014), (pp. 7-20).

[23] GERLICI, J., LACK, T. (2014). Rail vehicles brake components test bench utilisation In: Applied mechanics and materials. ISSN 1660-9336. - Vol. 486 (2014), online ISSN 1662-7482, (pp. 379-386).

[24] GERLICI J., LACK T., HARUŠINEC J. (2014). Rail vehicles wheels and brake blocks wear laboratory test stand utilization. In: Prace Naukowe. Transport: Analiza i ocena elementów systemów transportowych. ISSN 12309265. - Z. 101 (2014), (pp. 21-32).

[25] SUCHÁNEK, A., HARUŠINEC, J., GERLICI, J., LACK, T. (2013). Test stand for railway whels wear investigation function parts modification. (In Slovak). In: Computational and experimental methods in applied mechanics 
I. - Ústí nad Labem: Faculty of production technologies and management UJEP, 2013. ISBN 978-80-7414-609-1, (pp. 151-158).

[26] GERLICI J., LACK T., HARUŠINEC J. (2013). SIMRAIL - the load modulus of the test stand for the realistic simulation of railway operation in laboratory conditions. In: Dynamics of flexible and rigid bodies 2013: proceedings of the XI. International scientific conference, Ústí nad Labem, 9.-11.10 2013. FVTM UJEP, 2013. ISBN 978-80-7414-607-7. - CD-ROM, (p. 8).

[27] GERLICI J., LACK T., HARUŠINEC J. (2013). The test stand load modulus implementation for the realistic railway operation in the laboratory conditions. Paper number: M2013183. Manufacturing technology. Vol. 13, Nr.4., ISSN 1213-2489. Journal for science, research and production. December 2013. Issued by J.E. Purkyně University in Ústí nad Labem, Faculty of Production Technology and Management, (pp. 444 -449).

[28] ŠTEFAŇAKOVÁ, V., GERLICI J., LACK T., HARUŠINEC, J. (2013): Test stand load modulus construction proposal for the realistic simulation of railway operation. In: TRANSCOM 2013: 10th European conference of young researchers and scientists : Žilina, June 24-26, 2013, Slovak Republic. - Žilina: University of Žilina, 2013. ISBN 978-80-554-0695-4, (pp. 305-308).

[29] ŠTEFAŇAKOVÁ, V. (2013). Test stand loading modul for realistic simulation of rail vehicle operation (In Slovak). In: Experimental and computational method in engineering: Conference proceedings. 11. - 13. 6. 2014, Ústí nad Labem, Czech Republic. - Ústí nad Labem: Univerzita J. E. Purkyně], 2014. ISBN 978-80-7414-725-8. - CDROM, (p.10).

[30] SVOBODA, M., SOUKUP, J. (2013). Dynamic measurement of four-axle railway wagon. In: Manufacturing Technology. ISSN 1213-2489, 2013, vol. 13, iss. 4, (pp. 552-558).

[31] HARUŠINEC, J., GERLICI, J., LACK, T., ŠTEFAŇAKOVÁ, V. (2014). Angle of attack setting on the test stand system concept modification (In Slovak). In: Dynamics of flexible and rigid bodies 2014: Proceedings of the XII international scientific conference: Ústí nad Labem, 8.-10.10 2014. FVTM UJEP, 2014. ISBN 978-80-7414-7494. - CD-ROM, (p. 16).

[32] GERLICI, J., LACK T. (2003). Test benches computer control software tools development. In: Scientific bulletin of North University of Baia Mare: Fascicle: Mechanics, Tribology. Technology of Machine Manufacturing. ISSN 1224-3264. - Series C, Vol. XVII (2003), (pp. 181-186). 